\title{
Elżbieta Plucińska
}

Mgr inż.

Zakład Budowy Mostów i Dróg Kolejowych, Politechnika Poznańska

elzbieta.plucinska@put.poznan.pl

DOI: 10.35117/A_ENG_18_05_04

\section{Analysis of the infrastructure and organization of public transport at the Poznań Glówny Railway Station}

\begin{abstract}
In 2013 a newly built so-called Integrated Transport Centre (ZCK) in Poznań was opened. The centre, located on the border of Poznan's city center, connected railway and long-distance bus station with local transport. The new hub received a high criticism both from users and from engineers' clubs. The paper analyses the implemented solutions and proposes additional with a comparison. The analysis takes into account not only the time and distance to the hub's main buildings, but also comfort of changing transport modes, including local transport. Taken into account was also a problem of connecting the hub to a major interchange point for local transport, located $600 \mathrm{~m}$ away from the hub.
\end{abstract}

Keywords: Public transport; Railway station; Interchange

\section{Introduction}

In recent years, transport has determined the functioning of modern cities, and communication is currently the most important factor influencing their development [7]. The level of motorization in Poland increased from 195 cars per 1000 inhabitants in 1995 to 599 in 2016 [16], which led to traffic congestion, parking deficits or problems with traffic safety. Since there is no possibility, both economic and urban, to adapt the road system of cities to the growing demand for car traffic [6], it is necessary to get as many drivers as possible to change transport habits. In order to counteract the negative effects of individual motorisation, a number of activities in the field of traffic engineering are undertaken, one of the objectives of which is to improve and make public transport more attractive; only efficient and comfortable service of passengers will cause drivers and their passengers to choose a train or a bus $[12,13]$. Therefore, it is important to constantly improve the standard of public transport, and above all to increase its availability and shorten the time of travel.

In Poznań, the city transport network is based on trams as well as urban and suburban buses. Travelers using public transport can choose from 75 city bus lines and 20 tram lines. A well-functioning transport network should be supplemented with agglomeration railway, buses, suburban buses, and private carriers. A well-planned agglomeration railway network, synchronized spatially, temporarily and privately with municipal transport, would be competitive for road transport [3].

The number of Poznań residents is systematically falling in favor of neighboring communes, however, it is still the main center, including jobs and main services is Poznań [19]. This indicates the need to ensure both good quality of the agglomeration railway and its integration with urban transport. Due to the terrain restrictions at the main interchange point of public transport - Rondo Kaponiera - railway passengers change to urban transport by the Poznań Główny railway station - this station brings together all forms of land transport of the agglomeration: rail, tram, and bus (including long-distance bus)

\section{The efficiency of public transport}

From the passenger's point of view, effective public transport is one that provides a quick journey from the passenger's travel source to the destination. For this reason, both the 
lengthening of the route and the travel time of a public transport vehicle, as well as the size of the interchange are affecting efficiency. A separate issue is an efficiency from the point of view of the organizer or contractor - here the time and distance counted, as well as the buffer time necessary at the ends of the routes.

The efficiency of interchange points (places where at least two lines of public transport intersect) from the point of view of public transport passengers is measured using two basic indicators: loss of time associated with waiting for the arrival of the means of transport and the effort and time associated with the transition between stops within a given interchange node [5].

Crucial for transferring travelers is, therefore, the distance between the platform on which they get off, and the platform they want to continue their journey. Additional factors, also important, are barriers in the form of roadways with high traffic, traffic lights, on which pedestrians must wait long for a green signal or stairs, which enforce additional physical effort.

New interchange nodes projects should, therefore, increase their spatial integration [11], shorten the distance between the platforms and reduce the time losses associated with the mentioned barriers.

Another way of increasing the attractiveness of public transport is the use of tramway tracks adapted for the movement of city buses. Such a solution is called bus and tramway lanes (PAT) or tram and bus tracks (TTA) [2] and consists in the fact that both trams and buses use the same space in the cross-section of the street and stop at the same platforms into exchange passengers. The tram-bus track is most often used for two main purposes: for facilitating transfers between buses and trams, and for avoiding traffic congestion by buses, especially during rush hour [8].

\section{Description of the current situation at the PKP railway station in Poznań Railway station}

In 2013, newly constructed so-called Integrated Transport Center (ZCK) in Poznań, including not only the train and bus station but also the Poznan City Center shopping mall and a parking lot. The ZCK building has 3 functional levels, of which.

- at the station level, under the station building, there is a long-distance bus station and railway platforms,

- the building of the railway station is located on the +1 and +2 levels,

- shopping mall and parking are located on all three levels.

After the ZCK was built, closing the old station building and moving cash registers and information to the north-east in relation to the old building and the railway station center were the biggest passenger objections. The old railway station building, where ticket offices and information were located, is located centrally in relation to the tracks with platforms located along the east and west facade of the building. In addition, the old building is located on the level of tracks, and each platform can be accessed via an underpass (there is a 4-meter level difference to cover). However, a new building located above Platforms 1, 2 and 3, with direct descent to each of these platforms, requires a one-time overcome 7-meter difference in levels. Ticket offices are also located in the western building, the so-called West Railway Station, located at the end of the station tunnel.

The closing of the old station building has received many negative opinions and negotiations are under way to restore the station's function in this building. 


\section{Availability of ZCK}

Access by public transport to the ZCK is provided by both trams and buses. If you want to get to any of the railway station buildings, the passengers can choose from 8 tram lines stopping at 4 separate stops (Dworzec Zachodni (PST), Dworzec Zachodni, Most Dworcowy and Poznań Główny) and 5 day bus lines stopping at 3 separate stops (Dworzec Zachodni, Poznań Główny (at Dworcowa St.) and Poznań Główny (at King Przemysław II Avenue) .The arrangement of the above-mentioned stops is shown in Figure 1.

In 2013, the route of Poznański Szybki Tramwaj (PST) has been extended to the socalled Dworzec Zachodni, located $170 \mathrm{~m}$ from the old railway station building and $290 \mathrm{~m}$ from the new one. The launch of a new section of the route improved the flow and speed of travel from the northern districts of Poznan to the railway station and integrated urban and rail transport. Two tram lines from 8 previously serving the area of the station and 1 new one were launched along the new route, and access to the previously mentioned new Poznan Główny stop (at the intersection of Towarowa and Matyi streets) received 3 lines plus 1 line traveling along the PST route - availability of the remaining 3 lines remained changes - from previous stops. As demonstrated in [10], it would be necessary to increase the accessibility of public transport, in the most general terms defined as the total time of access from public transport to railway areas. Improvement of the accessibility of tram stops is possible to a limited extent through the formation of additional pedestrian routes and improvement of their equipment [10], but it is worth considering the improvement of accessibility from city buses.

The functional solutions used in the creation of the ZCK met with many negative opinions. Both in the local press [18], scientific publications [10] and statements of professional associations, one can find numerous comments criticizing the routes between railway platforms, the station building, and public transport stops, and postulates and proposals for solutions that can improve the situation. In the paper [10], the routes of travelers coming from public transport stops and parking lots to ticket offices, information and platforms and the length of these roads compared to the old and new train layout were compared. It was shown that the routes were extended, and thus the time of arrival of travelers arriving from the Most Dworcowy (to the old station: $290 \mathrm{~m}$, and to the new one: $320 \mathrm{~m}$ ), as well as buses, taxis and private cars leaving at the station square (to the old station: $100 \mathrm{~m}$, to the new one: $230 \mathrm{~m}$ ). The location of the new station and the new layout of the walk is more beneficial only for travelers heading to the station from the tram stop built specifically for the ZCK: Poznań Główny (to the old station: $495 \mathrm{~m}$, to the new one: $357 \mathrm{~m}$ ). So it is not surprising that the closure of the old railway station building raised so much controversy and social actions were created to restore the station's function to the old building. Directly to the Integrated Transport Center in Poznań, passengers will get five daily bus lines operating from three stops (Fig. 1):

- 45 finishing at Dworzec Zachodni,

- 51, 68 and L finishing at Dworcowa Street,

- 71 passing by ZCK.

Figure 1 shows the numbers of lines including public transport stops. The layout of the line is based on data from 2015.

Buses number 71 "give their passengers the lifts" to the ZCK building from the shopping mall side. Travelers from the above mentioned stop have $40 \mathrm{~m}$ to the gallery, and if they want to get to the railway station building, they have to cover the distance of over $300 \mathrm{~m}$ or go through the shopping mall. To get to the gallery entrance and then return to the route, the bus extends the journey time by 2 minutes. 


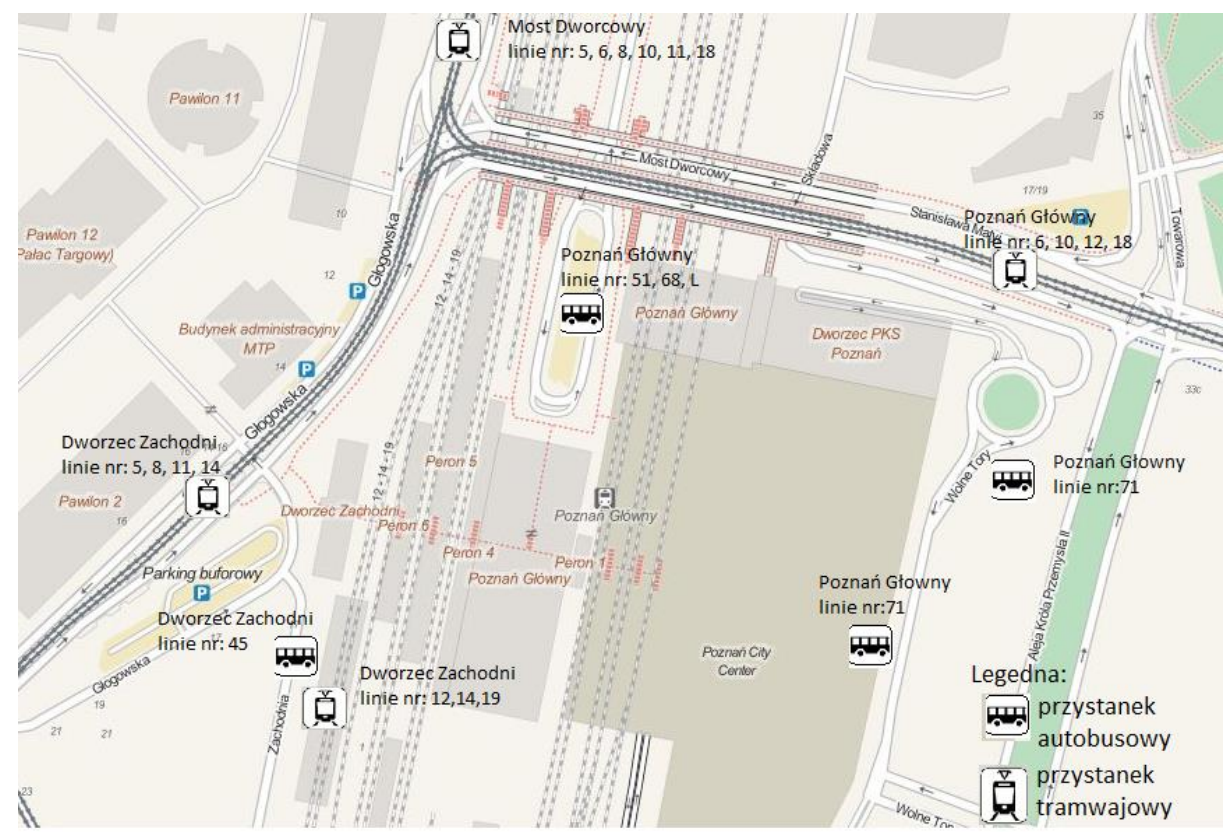

1. The distribution of public transport stops near the so-called Integrated Transport Center, including the Poznań Główny railway station, the PKS bus station and the Poznan City Center shopping mall. Elaboration: own based on the map [19].

\section{Rondo Kaponiera - the main interchange point of the city}

600 meters from the Integrated Communication Center, which means an 8-minute passage of a fit person, there is the Kaponiera Roundabout - recognized in documents as the main interchange point of the city. Via this interchange node, located on the border of the center of Poznań, there are 11 tram and 8 bus lines [5], thanks to which the possibility of changing between public transport lines is high. This node is currently being rebuilt.

The Rondo Kaponiera node includes not only tram stops within the intersection of the same name, but also the tram and bus stop "Battyk", away from the roundabout $200 \mathrm{~m}$, platforms of the "Rondo Kaponiera" bus stop, located $180 \mathrm{~m}$ west of Ronda at Zwierzyniecka Street, and the platforms of the "Rondo Kaponiera" stop at Dworcowa Street, 100 m away (Fig. 2). Overcoming the distance of $200 \mathrm{~m}$ and obligatory at the transition between the platforms of the stairs to the underpass takes about 3 minutes.

Buses number: 48, 59 and 77 finish their run at the "Rondo Kaponiera" stop at Zwierzyniecka Street and start the route at the "Bałtyk" stop. These lines provide passengers from the western part of Poznań, including some of them from the Ławica airport. It would be advisable to provide residents with good quality connections for trams going to the center (currently passengers wanting to change to the tram to the center have to cover a distance of $250 \mathrm{~m}$, and from the tram for a bus $300 \mathrm{~m}$ distance - Fig. 2), and residents and airport customers - also allowing access to the railway station. Access to this station is possible by bus L, connecting Ławica airport directly with the railway station, but it runs every 0.5 hours. You can also pass this distance on foot (as it has already been mentioned, the station is located at a distance of $600 \mathrm{~m}$ ) or go by bus 51 and 68 . 


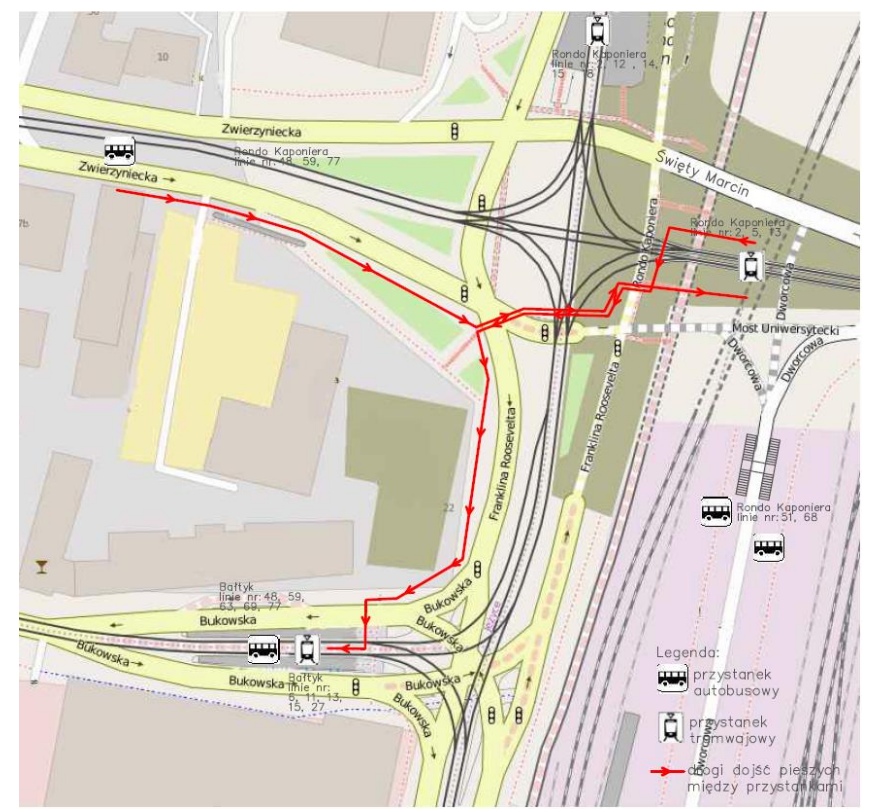

2. Interchange between buses from the direction of Ławica and trams going to the center. Elaboration: own based on the map [19].

Buses number 51 and 68 drive from the northern part of Poznań. As it has already been mentioned, the Rondo Kaponiera interchange node is currently being rebuilt and depending on the stages of construction works, the route of the public transport line changes. Before reconstruction, these buses, driving along Święty Marcin Street, they did not have the possibility of a direct turn in Dworcowa Street, therefore, they had to go around the Kaponiera Roundabout (picture 3). In the first stages of reconstruction, they were descending from Święty Marcin Street left on Dworcowa Street (Fig. 4), which significantly improved the passage. Turning back at Kaponiera Roundabout regarding the temporary route for the duration of the repair took an additional $120 \mathrm{~s}$ and lengthened the road by $240 \mathrm{~m}$, generating these congestions.

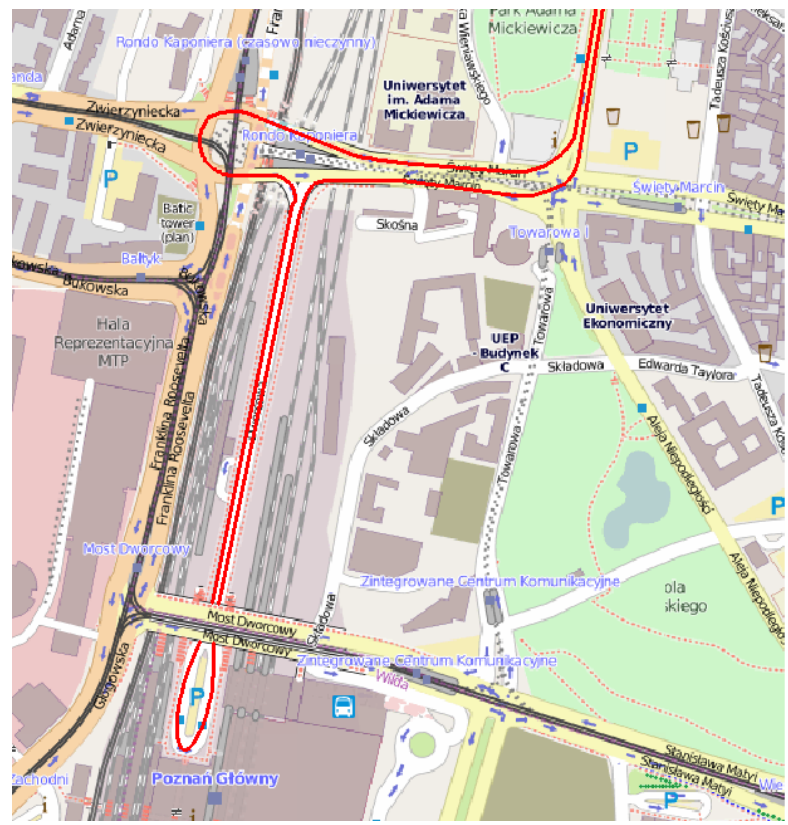

3. Bus route No. 51 and 68 near ZCK before the renovation of Rondo Kaponiera. Elaboration: own based on the map [19]. 
63 and 69 buses also pass through Rondo Kaponiera. These lines are run from the west along Bukowska Street (just like lines No. 48, 59, 77 and L), and after crossing through Kaponiera Roundabout they have a common route with lines No. 51 and 68 on a short fragment of Niepodległości avenue. Passengers of these lines can cross the Kaponiera Roundabout through transit, but if they want to change to a tram, they will encounter similar problems as passengers of the 48,59 and 77 lines.

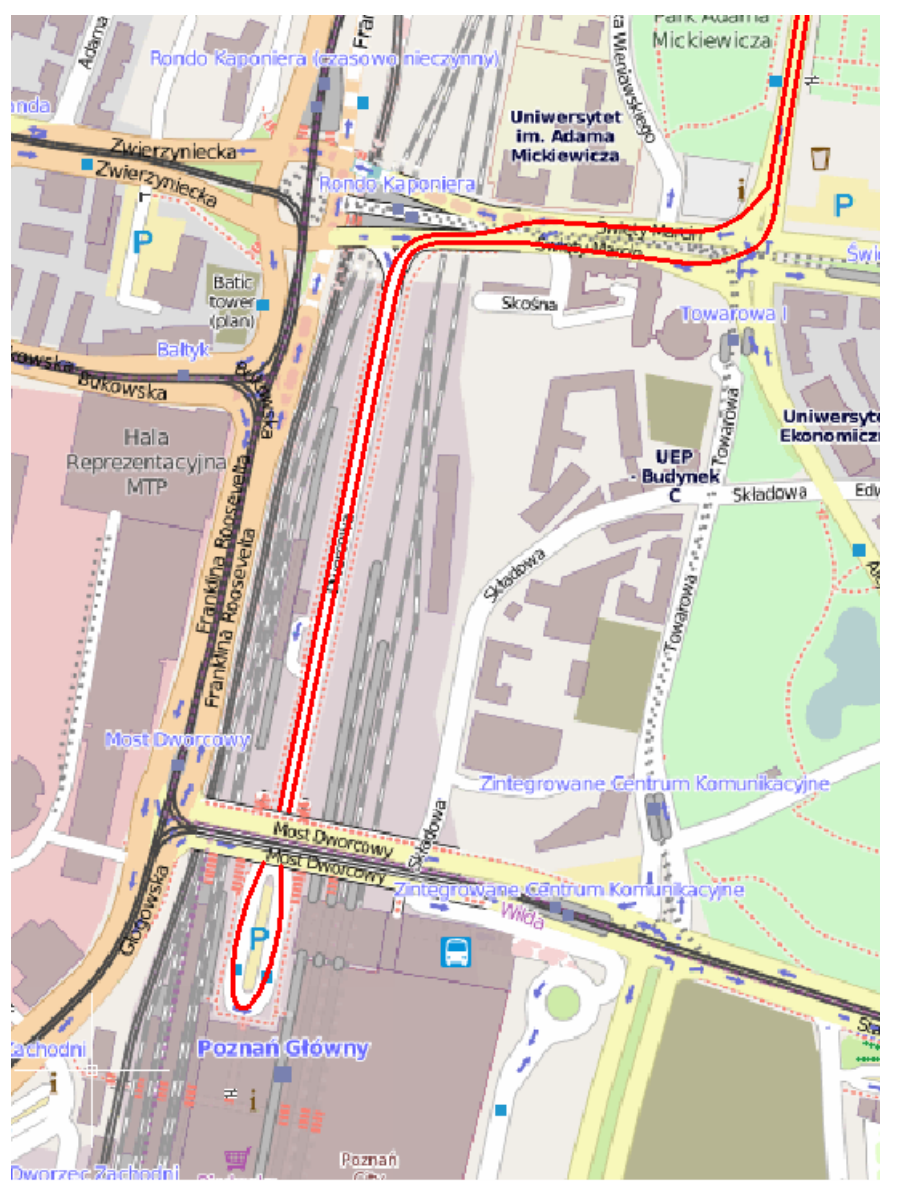

4. Bus route No. 51 and 68 near ZCK during the renovation of Rondo Kaponiera. Elaboration: own based on the map [19]

Extending the road and the time of travel of the means of public transport as well as the considerable distance between the platform on which the passengers get off and the platform of the line they want to continue their journey not only reduce its attractiveness, but also increase the costs associated with the crossing itself. The layout of railways around the Poznań Główny railway station is stiff, while the improvement of the organization of bus and pedestrian traffic around this station and the interchange Rondo Kaponiera should be considered as a key to encouraging passengers to use public transport.

\section{Suggested solutions. Buses number 51 and 68.}

Shortening the travel time of buses number 51 and 68 to the main railway station in Poznan is possible if these buses will evade the Kaponiera Roundabout. An alternative solution in the form of routing these buses as during the reconstruction (fig. 4) was rejected when making decisions about the shape of the modernization. It is possible to avoid the Kaponiera Rondo provided that these buses are dropped off at Dworcowa Street and directing them to the ZCK. The new route could lead through Towarowa and Składowa streets (Fig.5). The bus routes would be slightly shortened (by $35 \mathrm{~m}$ ) and the journey time to the station would also shorten, 
and by reducing the number of detentions it would also reduce fuel consumption. On a short section $(150 \mathrm{~m})$, buses would use the road for trams, whose track would have to be slightly reconstructed - expanded to allow passing the buses and trams. Driving the suggested route, buses would transport passengers to the long-distance bus station and $50 \mathrm{~m}$ from the entrance to the railway station. In comparison with the previous solution:

- travel time to the final bus stop would shorten by $165 \mathrm{~s}$, while the starting time from the initial stop would be comparable;

- the time to get to the train station and to train platforms 2 and 3 would shorten by $108.6 \mathrm{~s}$, but it would still be necessary to overcome the difference in levels;

- the time to reach the railway platforms 1 and 4 would extend by $101 \mathrm{~s}$ and would require a double level difference;

- $\quad$ time to reach the railway platforms 5 and 6 would be extended by $123 \mathrm{~s}$.

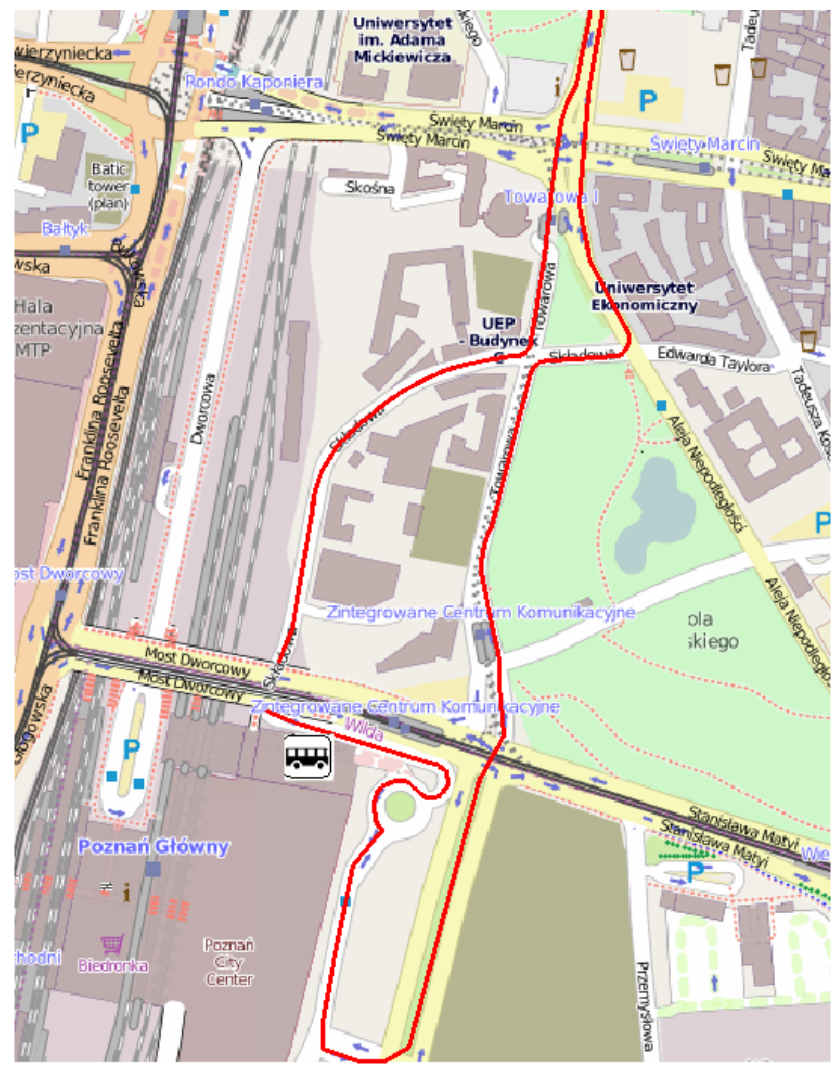

5. The proposed route of lines 51 and 68 buses near ZCK. A bus symbol shows the location of the final stop of these lines. Elaboration: own based on the map [19].

The disadvantage of this solution is the avoiding by passengers lines 51 and 68 of the main interchange point - Rondo Kaponiera. Passengers interchanging to trams going transversely to the course of the analyzed lines could use the Zamek stop, while passengers wanting to use trams parallel to the course of the analyzed lines would have to pass $300 \mathrm{~m}$ ( 5 minutes crossing including passages before roadways with traffic lights and the need to overcome the difference in levels). Passengers traveling to the Zamek stop must cover a distance of just over $200 \mathrm{~m}$, without overcoming the difference in levels, but crossing the road with traffic lights.

Another solution would be to route buses number 51 and 68 to Dworzec Zachodni stop through tram-bus trackway in Święty Marcin and Roosevelta Streets (it is not possible to use this track for the current route of these buses, as it is impossible to turn back at Kaponiera Roundabout). This solution would ensure good integration with trams, described in the 
chapter below, but it would extend the route by $814 \mathrm{~m}$, and the time of getting to the station by $170 \mathrm{~s}$ compared to the loop on Dworcowa Street. Compared with the ZCK loop, extending the journey time to the station would be $204 \mathrm{~s}$.

\section{Buses number 48,59 and 77}

As it has already been mentioned, the distance between the platform on which the travelers get off and the platform of the line they want to continue their journey is of key importance to transferring travelers. Passengers traveling by bus lines 48, 59 and 77 , wanting to change to the tram have to cover a distance of $200 \mathrm{~m}$. The solution would be to direct these buses to the tram and bus track on Święty Marcin Street, which would make it possible to change between one platform. This proposal eliminates the termination of these lines in the current location, so there is a question where to direct these buses. Location of tram and bus platforms on St. Marcin Street as part of the Rondo Kaponiera stop makes it impossible to direct these buses to Dworcowa Street - they can be traced to ZCK in a similar way to the solution presented for lines 51 and 68. The analogy would not be full, because the stop at the long-distance bus station would not be able to fit the 5 or even 3 lines. However, it is possible to locate the tip in the place shown in Fig. 6, and in the location described in section 4.1, only mark the stop. Passengers hurrying to a long-distance train or bus would, therefore, have the same conditions as described in section 4.1, while passengers transferring from a train or a long-distance bus would have to pass an additional $200 \mathrm{~m}$. The route from Bukowska Street to ZCK are shown in Figure 6.

Such a solution would bring the following benefits:

- Passengers of the lines 48, 59 and 77 would have direct access to the railway station, to the long-distance bus station, and they would change to the center on trams within one platform - without having to cross the platforms and use the stairs.

- In the future, these buses could be directed to serve the new district provided for in the post-railway areas (Figure 6).

The disadvantage is the extension of bus routes by $2.8 \mathrm{~km}$.

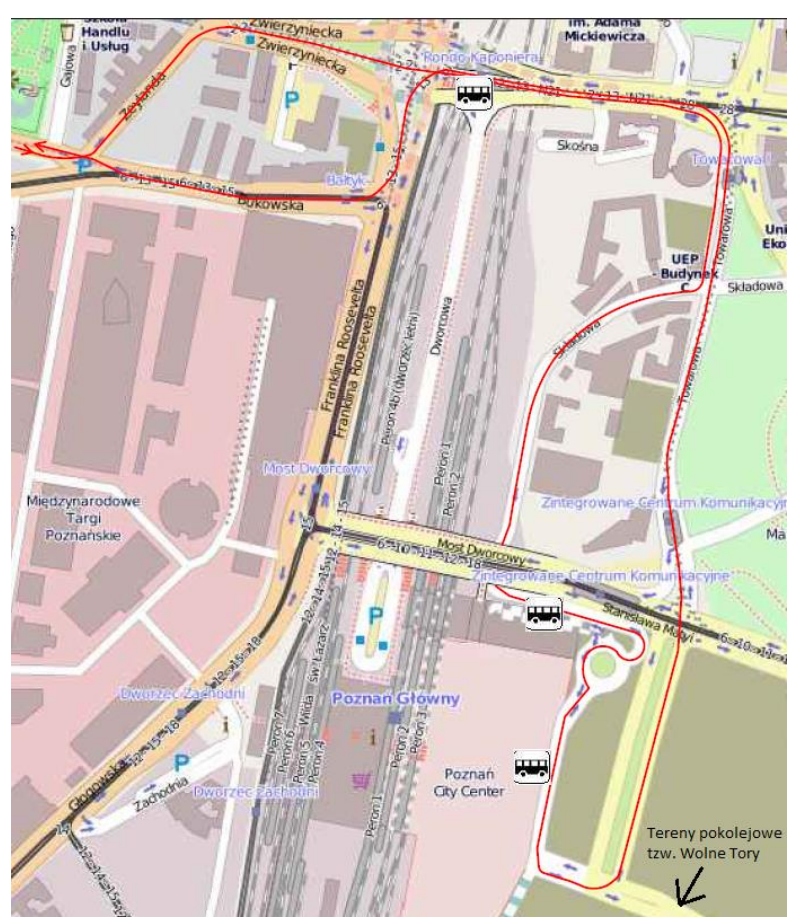

6. The proposed route of buses No. 48, 59 and 77 extended to the railway station. Bus symbol shows the location of the bus stops. Elaboration: own based on the map [19]. 


\section{Buses number 63, 69, and $L$}

The route of bus lines No. 63 and 69 should be changed so that these buses can also use the tram and bus platforms on St. Marcin Street (together with bus lines 48, 59 and 77), and then stop at the Zamek stop (along with bus lines 51 and 68). Using the tram and bus track at Kaponiera Roundabout would bring the same advantages as for the other bus lines - change on one platform and gain on intersection capacity.

The $\mathrm{L}$ bus route, running between the airport and the main station, should remain unchanged and end up on Dworcowa Street. The airport character of the bus justifies the preservation of such a route, without improving the accessibility for a change at the Kaponiera Roundabout.

\section{The effects of the suggested changes to the bus system layout}

Table 1 presents a comparison of the suggested solutions in relation to the system from before the reconstruction. The length of the route, the transition times between the interchange platforms and the railway station and bus station as well as the capacity of the Kaponiera Roundabout were taken into account.

Tab. 1.: Comparison of the proposed solutions to the state before the reconstruction

\begin{tabular}{|c|c|c|c|c|}
\hline Line number & $\begin{array}{l}51 / 68 \text { to } \\
\mathrm{ZCK}\end{array}$ & $\begin{array}{c}51 / 68 \text { to } \\
\text { Dw. Zachodni }\end{array}$ & $48 / 59 / 77$ & $63 / 69$ \\
\hline Criterion & $\begin{array}{c}\text { decrease by } \\
35 \mathrm{~m}\end{array}$ & $\begin{array}{c}\text { increase by } \\
690 \mathrm{~m}\end{array}$ & $\begin{array}{c}\text { increase by } \\
2695 \mathrm{~m}\end{array}$ & the same \\
\hline $\begin{array}{l}\text { increase / decrease the } \\
\text { length of the route }\end{array}$ & $\begin{array}{c}\text { decrease by } \\
109 \mathrm{~s}\end{array}$ & $\begin{array}{c}\text { increase by } \\
150 \mathrm{~s}\end{array}$ & $\begin{array}{c}\text { decrease by } \\
394 \mathrm{~s}\end{array}$ & the same \\
\hline $\begin{array}{l}\text { increase / decrease the time } \\
\text { to reach the railway station }\end{array}$ & $\begin{array}{c}\text { decrease by } \\
237 \mathrm{~s}\end{array}$ & $\begin{array}{c}\text { increase by } \\
150 \mathrm{~s}\end{array}$ & $\begin{array}{l}\text { decrease by } \\
430 \mathrm{~s}\end{array}$ & the same \\
\hline $\begin{array}{l}\text { increase / decrease of the } \\
\text { time of access to the bus } \\
\text { station }\end{array}$ & $\begin{array}{l}\text { increase by } \\
103 \mathrm{~s}\end{array}$ & $\begin{array}{c}\text { decrease by } \\
76 \mathrm{~s}\end{array}$ & $\begin{array}{l}\text { decrease by } \\
270 \mathrm{~s}\end{array}$ & $\begin{array}{c}\text { decrease by } \\
307 \mathrm{~s}\end{array}$ \\
\hline $\begin{array}{l}\text { increase / decrease of the } \\
\text { time of access to trams to } \\
\text { the center }\end{array}$ & $\begin{array}{l}\text { increase by } \\
\quad 95 \mathrm{~s}\end{array}$ & $\begin{array}{c}\text { decrease by } \\
68 \mathrm{~s}\end{array}$ & $\begin{array}{l}\text { decrease by } \\
270 \mathrm{~s}\end{array}$ & $\begin{array}{c}\text { decrease by } \\
311 \mathrm{~s}\end{array}$ \\
\hline $\begin{array}{l}\text { increase / decrease of the } \\
\text { time of getting trams from } \\
\text { the center (medium time) }\end{array}$ & $\begin{array}{l}\text { increase by } \\
\quad 81 \mathrm{~s}\end{array}$ & $\begin{array}{c}\text { decrease by } \\
12 \mathrm{~s}\end{array}$ & $\begin{array}{c}\text { decrease by } \\
173 \mathrm{~s}\end{array}$ & $\begin{array}{c}\text { increase by } 60 \\
\text { s }\end{array}$ \\
\hline $\begin{array}{l}\text { increase / decrease of the } \\
\text { time of access to trams in } \\
\text { the NS axis (medium time) }\end{array}$ & increase & increase & the same & increase \\
\hline
\end{tabular}

The table shows that in all aspects the suggested layout is better than the old one. Analyzing the above list, it is difficult to choose the best solution for bus lines 51 and 68. In the case of route guidance to the ZCK, the accessibility to the railway and bus stations would be improved, however, the time of access to tram stops and railway platforms is longer. Yet, in the second proposal of the route - leading to the West Railway Station, contrary to the first proposal, the times of transition to tram stops are decreasing, however, the availability to the stations is getting worse. In both cases the capacity of the Kaponiera Roundabout will increase. Analyzing the routes of buses No. 4859 and 77, we can clearly see the shortening of the transition times both to railway and bus stations as well as to tram stops. Although the 
route will be increased by more than $2.5 \mathrm{~km}$, but it is definitely a big advantage to take passengers to the station itself or change to a tram within one platform. In the case of bus numbers 63 and 69, as mentioned, the routes will not change, only they will use the tram and bus track. As a result, the place of the stop will change and the times of reaching the tram stops will decrease.

\section{Summary}

Proper organization of urban public transport is a challenge that cities must constantly face when deciding on such a service. The level of the challenge is the bigger the bigger the city or the whole agglomeration is [1].

When planning the route of the line and the placement of stops, solutions should be used to ensure the passenger's greatest possible convenience and ease of movement [4]. In the reconstruction of such important interchange points as are the vicinity of the railway station, it is important to carefully analyze and select the best possible variants. This article shows that the best solutions have been rejected.

It has been shown that the use of tram-bus trackways will bring benefits, in particular, such as the improvement of transfer and increase of bandwidth Kaponiera roundabout - crowded during the rush hour.

The solutions indicated in this article improve the conditions of service for passengers using public transport, however, analyzes of public transport should be continued using modern methodology [9].

\section{Source materials}

[1] Birr K. Struktury sieci transportu zbiorowego z miastach. W: Krych A., Rychlewski J. Wydajność systemów transportowych. SITK, Poznań 2013, s. 287-296.

[2] Brzeziński A., Sambor A. Uwarunkowania dotyczące wprowadzenia ruchu autobusów komunikacji miejskiej na torowiska tramwajowe. Transport Miejski, 2003, 5, s. 9-11.

[3] Bul R., Kaczmarek T. Społeczne uwarunkowania rozwoju kolei metropolitalnej w aglomeracji poznańskiej. Biblioteka Aglomeracji Poznańskiej, Bogucki Wydawnictwo Naukowe, 2014, 25.

[4] Gadziński J., Beim M. Dostępność przestrzenna lokalnego transportu publicznego w Poznaniu. Transport Miejski i Regionalny, 2009, 5, s. 10-16.

[5] Gadziński J., Beim M. Ewaluacja węzłów przesiadkowych poznańskiego lokalnego transportu publicznego. Transport Miejski i Regionalny, 2009, 8, s. 18-24.

[6] Krych A., Rychlewski J. Raport Buchanana 50 lat później. W: Krych A., Rychlewski J. Wydajność systemów transportowych, SITK, Poznań 2013, s. 371-400.

[7] Majewski B., Beim M. Dostępność komunikacji publicznej w Poznaniu. Biuletyn Instytutu Geografii Społeczno-Ekonomicznej i Gospodarki Przestrzennej Uniwersytetu im. Adama Mickiewicza w Poznaniu, seria „Rozwój Regionalny i Polityka Regionalna” nr 3, 2008, s. $115-124$.

[8] Makuch J. Pasy autobusowo-tramwajowe jako rozwiązanie systemowe na obszarze centrum miasta. III Konferencja Naukowo-Techniczna: Problemy komunikacyjne miast w warunkach zatłoczenia motoryzacyjnego. Poznań 15-17 maja 2001, s. 258-267

[9] Olszewski P., Krukowski P. Wskaźnikowa metoda oceny węzłów przesiadkowych, transportu publicznego, W: Krych A.: Nowoczesny transport publiczny. Poznań 2011, s. 323 -349 .

[10] Plucińska E., Kosicki D. Warunki obsługi pasażerów na stacji Poznań Główny po budowie Zintegrowanego Centrum Komunikacyjnego. Technika Transportu Szynowego, 2014, 7-8, s. 56 - 61. 
[11] Rychlewski J. Accessibility of Public Transport Stops on the Example of the City of Poznan, W: Janecki R., Sierpiński G. The Development of Transport Systems. Wyd. Politechniki Śląskiej, 2012, s. $341-350$.

[12] Rychlewski J. Doświadczenia za stosowania priorytetu tramwajowego w Poznaniu, W: Materiały konferencyjne. Zintegrowany system transportu miejskiego. 27-28 maja 2010, s. 77-88.

[13] Rychlewski J. Potencjał transportowy sieci kolejowej aglomeracji poznańskiej. XII Konferencja Naukowa „Drogi kolejowe '2003”. 15-17 października 2003, s. 291-305.

[14] Starowicz W. Jakość przewozów w miejskim transporcie zbiorowym. Wydawnictwo Politechniki Krakowskiej, Kraków 2007

[15] Staszak J., Wyszomirski O. Ranking postulatów przewozowych i ich wpływ na preferencje komunikacyjne mieszkańców Gdyni. Transport Miejski i Regionalny, 2005, 10, s. $10-21$.

[16]www.newsweek.pl/styl-zycia/liczba-samochodow-w-polsce-europie-i-na-swieciestatystyki-,artykuly,394554,1.html, 21.11.2016.

[17] www.openstreetmap.org, 05.10.2015

[18]www.poznan.gazeta.pl/poznan/1,37794,13497946,Najkrotsza_droga_na_pociag_Przez_ galerie_handlowa.html, 04.03.2013

[19]www.transport-publiczny.pl/wiadomosci/aglomeracja-poznanska-przymierza-sie-dokolei-metropolitalnej-2201.html, 03.04.2016 